\title{
Neuronal migration and molecular conservation with leukocyte chemotaxis
}

\author{
Yi Rao, ${ }^{1,3}$ Kit Wong, ${ }^{1}$ Michael Ward, ${ }^{1}$ Claudia Jurgensen, ${ }^{1}$ and Jane $\mathrm{Y} . \mathrm{Wu}^{2}$ \\ ${ }^{1}$ Department of Anatomy and Neurobiology and ${ }^{2}$ Departments of Pediatrics and Molecular Biology and Pharmacology, \\ Washington University School of Medicine, St. Louis, Missouri 63110, USA
}

Cell migration is essential in species ranging from bacteria to humans (for recent reviews, see Lauffenburger and Horwitz 1996; Mitchison and Cramer 1996; Montell 1999|. In the amoebae Dictyostelium discoideum, cell migration is involved in chemotaxis toward food sources and in aggregation (for review, see Devreotes and Zigmond 1988; Parent and Devreotes 1999; Chung et al. 2001). In higher vertebrates, cell migration plays crucial roles in multiple physiological and pathological processes. During embryonic and neonatal development, cell migration is crucial in morphogenetic processes such as gastrulation, cardiogenesis, and the formation of the nervous system (for review, see Hatten and Mason 1990; Rakic 1990; Hatten and Heintz 1998; Bentivoglio and Mazzarello 1999). In adult animals, cell migration is required for leukocyte trafficking and inflammatory responses (for review, see McCutcheon 1946; Harris 1954; Devreotes and Zigmond 1988). In tumoriogenesis, tumor-induced angiogenesis and tumor metastasis both involve cell migration. Although it is well known that cell migration is necessary for all these processes, our understanding of mechanisms controlling cell migration is still limited. Here we briefly review the significance of neuronal migration and focus on recent studies on the directional guidance of neuronal migration, discussing the possibility that guidance mechanisms for neurons are conserved with those for other somatic cells.

\section{Ontogenetic and phylogenetic significance of neuronal migration}

Although the idea of neuronal migration was proposed in the late 1800s through the observations of Kolliker, His, Vignal, and Ramon y Cajal (Bentivoglio and Mazzarello 1999), there was a long-standing debate as to whether there is active neuronal migration or only passive neuronal displacement (e.g., Tilney 1933). A large amount of work based on histology, autoradiography, retroviral tracing, dye labeling, and modern imaging have now established that the majority of, if not all, neurons actively

${ }^{3}$ Corresponding author.

E-MAIL raoyi@thalamus.wustl.edu; Fax (314) 362-3446.

Article and publication are at http://www.genesdev.org/cgi/doi/10.1101/ gad.1005802. migrate in the developing CNS /Angevine and Sidman 1961; Rakic 1971a,b, 1972; Nowakowski and Rakic 1979; Hatten and Liem 1981; Mason et al. 1988; Gray et al. 1990; Walsh and Cepko 1990; Hatten and Heintz 1998).

Neuronal migration is essential for the formation and normal functioning of the nervous system. Many human diseases are caused by defects in neuronal positioning (e.g., Volpe 1987; Reiner et al. 1993; Norman et al. 1995; Flint and Kriegstein 1997). Although some diseases such as lissencephaly (smooth brain) are easily explained by developmental abnormalities, others, such as epilepsy and autism, are not immediately obvious and are most likely indirect consequences of abnormal neuronal positioning. In addition, migration is also important for metastasis or invasion of neuroblastoma and glioma (e.g., Giese and Westphal 1996). Genetic studies of defects affecting neuronal positioning in humans and mice have helped further our understanding of neuronal migration (for recent reviews, see Dhavan and Tsai 2001; Rice and Curran 2001; Ross and Walsh 2001). For example, an interesting pathway that has emerged from these studies consists of the secreted protein Reelin, the ApoE receptor, the very low density lipoprotein (VLDL) receptor, and the cytoplasmic protein Disabled (Dbl), and has been revealed to play a role in neuronal positioning, a topic that has been recently reviewed by Rice and Curran (2001).

In addition to playing a critical role in early development and disease, neuronal migration is also important for changes in the adult brain. In birds, neuronal migration is required for postnatal behavior changes (Nottebohm 1981; Goldman and Nottebohm 1983; for review, see Alvarez-Buylla and Kirn 1997; Goldman and Luskin 1998; Nottebohm 2002). Findings of neurogenesis and adult neural stem cells suggest that neuronal migration is also important in the brains of adult mammals, including humans (Altman 1962; Reynolds and Weiss 1992; for review, see Gage 2000; Alvarez-Buylla and García-Verdugo 2002; Gould and Gross 2002; Rakic 2002). Because neuronal stem cells give rise to neurons during neural plasticity (Greenough et al. 1978; Kempermann 2002), neuronal migration can be essential for neural plasticity, although it is unknown whether neuronal migration is regulated in neural plasticity. 
An additional role for neuronal migration in brain evolution has been proposed by Rakic and colleagues (Letinic and Rakic 2001). Comparative studies of neuronal migration between humans and monkeys have led to the suggestion that establishment of new routes of neuronal migration might contribute to the evolution of the human brain (Ogren and Rakic 1981; Letinic and Rakic 2001; Rao and Wu 2001; Letinic et al. 2002). Regions connected to each other anatomically and functionally are thought to coevolve during the evolution of the mammalian brain (Barton and Harvey 2000). The establishment of a new migratory pathway between two functionally connected regions may contribute to the coevolution of the frontal cortex and the thalamic nuclei (Letinic and Rakic 2001).

\section{Radial and tangential modes of migration}

According to the direction of neuronal migration relative to the surface of the CNS, neuronal migration can be classified into radial and tangential modes. A cellular model for radial migration based on reconstruction of sections examined by electron microscopy proposes that neurons migrate along radially aligned glial fibers (Rakic 1971a,b, 1972, 1978, 1990; Levitt and Rakic 1980). This model is supported by later observations using retroviral tracing, immunohistochemistry (Misson et al. 1991), and in vitro studies of live granule cells from the cerebellum (Hatten and Liem 1981; Edmondson et al. 1988; Gregory et al. 1988; Mason et al. 1988; Hatten and Mason 1990). Further in vitro studies have shown that granule cells can also migrate along glass fibers coated with extracellular matrix proteins such as laminin or fibronectin (Fishell et al. 1993), suggesting that extracellular matrix proteins could provide substrate along which neurons can migrate.

Recent studies have indicated that there are two modes of radial migration (Nadarajah et al. 2001; Nadarajah and Parnavelas 2002): somal translocation and locomotion (Fig. 1). Locomotion is the classical radial glia- dependent neuronal migration involving the migration of an entire cell, including its processes and the cell body. Somal translocation involves a neuron whose process is attached to the pia (a part of the meninges) and its cell body translocates as the process becomes shorter. The same neuron can have both modes of migration, first moving by locomotion and later by somal translocation once its leading process touches the pia (Nadarajah et al. 2001; Nadarajah and Parnavelas 2002).

Tangential migration of neurons occurs along pathways parallel to the surface of the CNS. Although tangential migration was observed in the 1960s (Altman and Das 1966; Hicks and D'Amato 1968; Hinds 1968; Altman 1969; Rakic and Sidman 1969), its importance is better appreciated after findings of tangential migration in multiple regions of the CNS including the telencephalon, the cerebellum, and the spinal cord (Table 1; for review, see Parnavelas 2000; Corbin et al. 2001; Marin and Rubenstein 2001).

Unlike radial migration, tangential migration does not rely on glial fibers. In some structures such as the pontine nuclei, migration depends on interactions with axonal pathways (Rakic 1990). In other structures, such as the adult rostral migratory stream (RMS), tangential migration relies on astrocytes, which have been implicated in forming tubular structures through which chains of neurons migrate (Lois et al. 1996; Alvarez-Buylla and García-Verdugo 2002). In vitro, tangential migration of some cell types is independent of other cells. For example, neuronal precursor cells from the medial ganglionic eminence (SVZa) in the postnatal forebrain or the embryonic lateral ganglionic eminence (LGE) and the medial ganglionic eminence (MGE) can migrate individually in a three-dimensional collagen matrix without relying on other cells (Wu et al. 1999; Zhu et al. 1999; Wong et al. 2001). Thus, the roles of axonal or glial fibers in tangential migration are not clear.

Some cells can undergo both tangential and radial migration. For example, cells in the external germinal layer (EGL) of the cerebellum migrate tangentially before they change the migration mode to that of classic radial mi-

Figure 1. Routes of neuronal migration. A diagram of an embryonic rodent brain is shown on the left. Two examples of tangential migration are colored in red and green. MGE, medial ganglionic eminence; LGE, lateral ganglionic eminence. A diagram of the coronal section of the neocortex is shown on the right. There are two modes of radial migration: somal translocation and locomotion. Neurons migrating by somal translocation is shown in $a$, neurons migrating by glial-dependent locomotion is shown in $b$, and neurons migrating tangentially is shown in $c$.

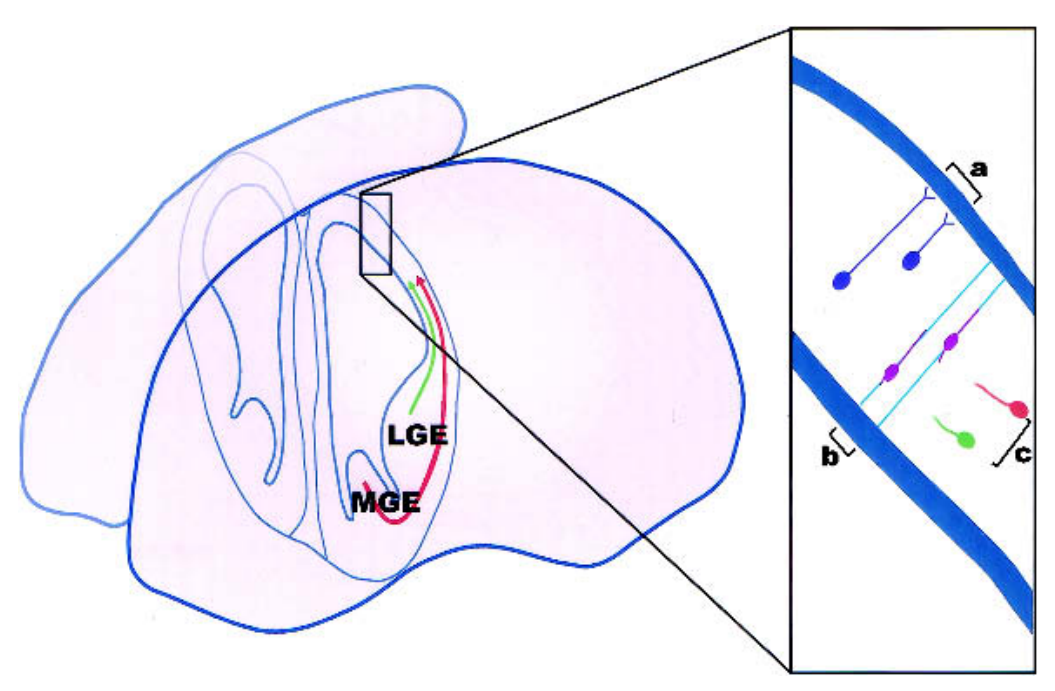


Table 1. Examples of tangential migratory pathways in the brain

\begin{tabular}{lll}
\hline Origin & \multicolumn{1}{c}{ Destination } & \multicolumn{1}{c}{ References } \\
\hline URL & Cerebellar EGL & Alder et al. 1996; Altman and Bayer 1997; Wingate and Hatten 1999; Wingate 2001 \\
URL & Midhindbrain boundary & Koster and Fraser 2001 \\
LGE & OB and neocortex & Anderson et al. 1997; Zhu et al. 1999; Wichterle et al. 2001; Nadarajah et al. 2002 \\
SVZa & OB & Altman and Das 1966; Altman 1969; Luskin 1993; Lois and Alvarez-Buylla 1994; Hu et al. \\
& & 1996; Wichterle et al 1997; Wu et al. 1999 \\
MGE & Striatum and neocortex & Van Eden et al. 1989; Yan et al. 1992; DeDiego et al. 1994; De Carlos et al. 1996; Anderson et \\
& & al. 1997; Tamamaki et al. 1997; Lavdas et al. 1999; Zhu et al. 1999; Marin et al. 2000; \\
& & Wichterle et al. 2001; Nadarajah et al. 2002 \\
\hline
\end{tabular}

URL, upper rhombic lip; LGE, lateral ganglionic eminence; MGE, medial ganglionic eminence; OB, olfactory bulb; SVZa, subventricular zone in the anterior forebrain; EGL, external germinal layer.

gration (Komuro et al. 2001). After EGL cells radially migrate into the internal granular layer, these new granule cells can detach from the radial glial cells (Bergmann glia) and migrate farther in a radial direction but in a manner independent of the Bergmann glial fibers (Komuro and Rakic 1998). It is unclear what determines the migratory mode taken by a neuronal precursor cell or the transition between different modes of migration.

\section{Cell adhesion and neuronal migration}

Cell adhesion is important for both radial and tangential migration. Antibody perturbation studies have suggested roles for several cell adhesion molecules in radial migration. For example, antibodies against the cell adhesion molecules astrotactin, tenascin, and thrombospondin, or those against $\alpha_{3} \beta_{1}$ integrin can inhibit the migration of glial cells (Edmondson et al. 1988; O'Shea et al. 1990; Husmann et al. 1992; DeFreitas et al. 1995). Antibodies against astrotactin and $\alpha_{3} \beta_{1}$ integrin inhibit neuronal association with glial fibers (Stitt and Hatten 1990; Fishell and Hatten 1991; Cameron and Rakic 1994; Anton et al. 1996, 1999; Zheng et al. 1996), suggesting that the migratory defects may be a result of reduced association with glial fibers.

Adhesion molecules have also been shown to be important in tangential migration. For example, the polysialylated form of the neural cell adhesion molecule $(\mathrm{N}$ CAM), the cell adhesion molecule TAG-1, and the NgCAM binding protein DM-GRASP have been implicated to play important roles in the tangential migration of different cell types (Tomsiewicz et al. 1993; Ono et al. 1994; Hu et al. 1996; Chazal et al. 2000; Heffron and Golden 2000; Denaxa et al. 2001; Kyriakopoulou et al. 2002).

Although gene targeting studies have confirmed the importance of astrotactin in granule cell association with glial fibers (Adams et al. 2002), it has been observed that mice lacking the $\beta_{1}$ integrin gene do not show defects in cortical migration (Graus-Porta et al. 2001). Thus, additional studies will be needed to determine the biological roles of the different adhesion molecules in neuronal migration. It will also be interesting to investigate the relationship between cell adhesion and directional guidance.

\section{Directional guidance of neuronal migration: slit as a guidance cue}

Although the previously mentioned adhesion molecules, glial fibers, and neuronal axons are important for neuronal migration and may limit the dimension in which neurons can move, they do not provide sufficient information to guide the direction of neuronal migration. Instead, secreted molecular cues have been shown to play important roles in guiding neuronal migration. A general principle from recent studies is that guidance cues for neuronal migration are shared with those for axon projection. There are four families of axon guidance cues known. We will use the Slit family as a primary example, before discussing other axonal guidance cues and their roles in neuronal migration.

The Slit gene was first discovered in a genetic screen for defects in embryonic pattern formation in Drosophila (Nusslein-Volhard et al. 1984). Slit genes have now been found in a wide range of species from Caenorhabditis elegans to humans (for review, see Wong et al. 2002). The Drosophila Slit protein contains an $\mathrm{N}$-terminal signal peptide, four leucine-rich repeats (LRRs), seven EGF repeats, a laminin G domain, and a C-terminal cysteinerich motif (or cysteine knot; Rothberg et al. 1988, 1990; Rothberg and Artavanis-Tsakonas 1992). Vertebrate Slit proteins are similar to Drosophila Slit except that they contain nine EGF repeats.

Initial characterizations of Drosophila slit mutants led to the conclusion that Slit was involved in midline cell differentiation, whereas its phenotype of the apparent fusion of longitudinal axons was thought to be secondary to cell differentiation defects (Rothberg et al. 1988, 1990). In 1999, work by three labs on Drosophila and vertebrates independently demonstrated that Slit was a diffusible chemorepellent for axons in Drosophila (Kidd et al. 1999) and mammals (Brose et al. 1999; Li et al. 1999). Thus, Slit acts directly on axons to direct their projection. Since then, Slit proteins have been shown to be potent repellents for axons in a variety of regions (for review, see Wong et al. 2002).

In addition to its role in axonal guidance, Slit plays a role in the directional guidance of neuronal migration. Such a role for Slit was first demonstrated in the RMS from the SVZa to the olfactory bulb (Wu et al. 1999), which relays information from the olfactory epithelium 
to the olfactory cortex. Coculture experiments indicated that the septum at the midline of the telencephalon was repulsive to the $\mathrm{SVZa}$ neurons ( $\mathrm{Hu}$ and Rutishauser 1996; Wu et al. 1999). Two of the three mammalian Slit genes are expressed in the septum (Wu et al. 1999). When SVZa explants are cocultured in vitro with an aggregate of Slit-expressing cells (Wu et al. 1999) or with purified Slit proteins (Hu 1999), Slit is able to repel SVZa neurons. Thus, these data suggest that the repulsive activity in the septum is due to the expression of the Slit genes.

Slit also repels other cell types, including GABAergic neurons containing that migrate tangentially from the ganglionic eminence to the neocortex in the embryo (Zhu et al. 1999; Fig. 2) and cells that migrate radially from the ventricular zone of the neocortex ( $\mathrm{Hu} 1999)$.

The concentration gradient of Slit is important for its function as a repellent in vitro (Wu et al. 1999). When SVZa explants are cocultured with the septum in the presence of the extracellular domain of the Slit receptor Roundabout (Robo), the repulsive effect of the septum on SVZa neurons is reduced (Wu et al. 1999), suggesting that that Slit contributes to the repulsive activity in the septum. Although these results indicate that Slit can repel SVZa neurons, it should be noted that the role of endogenous Slits (or the septum) in SVZa migration has not been demonstrated, and, although Slit can repel neurons within the radius of $1 \mathrm{~mm}$ in vitro, the effective distance of endogenous Slit is unknown.

The idea that the same molecule can function in neuronal migration and axon guidance is supported not only by the roles of Slit on both axon guidance and neuronal migration (Wu et al. 1999), but also by the finding that the same motifs in the Slit protein are involved in both activities (Battye et al. 2001; Chen et al. 2001; NguyenBa-Charvet et al. 2001b). The N-terminal LRRs of Slit are sufficient to repel both projecting axons and migrating neurons (Chen et al. 2001).

A recent paper reports that Slit functions only as an inhibitor to reduce the speed of neuronal migration but not as a repellent to change the direction of neuronal migration, and that Slit acts as a repellent only in the presence of a glial-derived migration-inducing activity (Mason et al. 2001). Further work is needed to determine whether Slit functions as a repellent or an inhibitor.

\section{Multiple molecular cues guide neuronal migration}

Four families of axon guidance cues are known: netrins (Colamarino and Tessier-Lavigne 1995), semaphorins (Semas; Kolodkin 1996; Raper 2000), ephrins (Flanagan and Vanderhaeghen 1998), and Slits. Netrins usually function as attractants, whereas the others are often repellents. Ephrins are membrane bound, whereas the others are diffusible. They all function by binding to their transmembrane receptors. There is now evidence that they are not only involved in axon guidance, but all four families are also involved in neuronal migration.

Neurons from the dorsal rhombencephlic neuroepithelium migrate ventrally and rostrally, eventually residing in several nuclei including the basilar pontine nuclei and the inferior olivary nuclei. Neurons in the pontine migratory stream end up in the basilar pons, which are located near the ventral midline (the floor plate). Netrin is expressed in the floor plate, whereas the migrating neurons express their receptor Deleted-in-Colorectal-Cancer (DCC; Yee et al. 1999). Netrin attracts neurons migrating toward the basilar pons (Yee et al. 1999; Alcantara et al. 2000). Netrin may also serve as a stop signal for neurons migrating circumferentially from the dorsal rhomb-
Figure 2. Directional guidance of neuronal migration by slit. This image shows how lateral ganglionic eminence (LGE) neurons behave in the presence of the repellent molecule Slit. An aggregate of human embryonic kidney (HEK) cells transfected with Slit cDNA was placed on the left side. An explant of LGE was placed on the right. The cells were cocultured in a three-dimensional gel matrix overnight. TUJ1 staining for neuronal specific tubulin is shown in green and anti-GABA staining in red (to show that these neurons contain the neurotransmitter GABA). Normally, cells migrating out of an LGE explant would be distributed symmetrically around its circumference. In the presence of Slit supplied from a point source, however, there are more cells in the quadrant distal to the Slit source than in the proximal quadrant. This result suggests that Slit is a repellent for LGE cells.

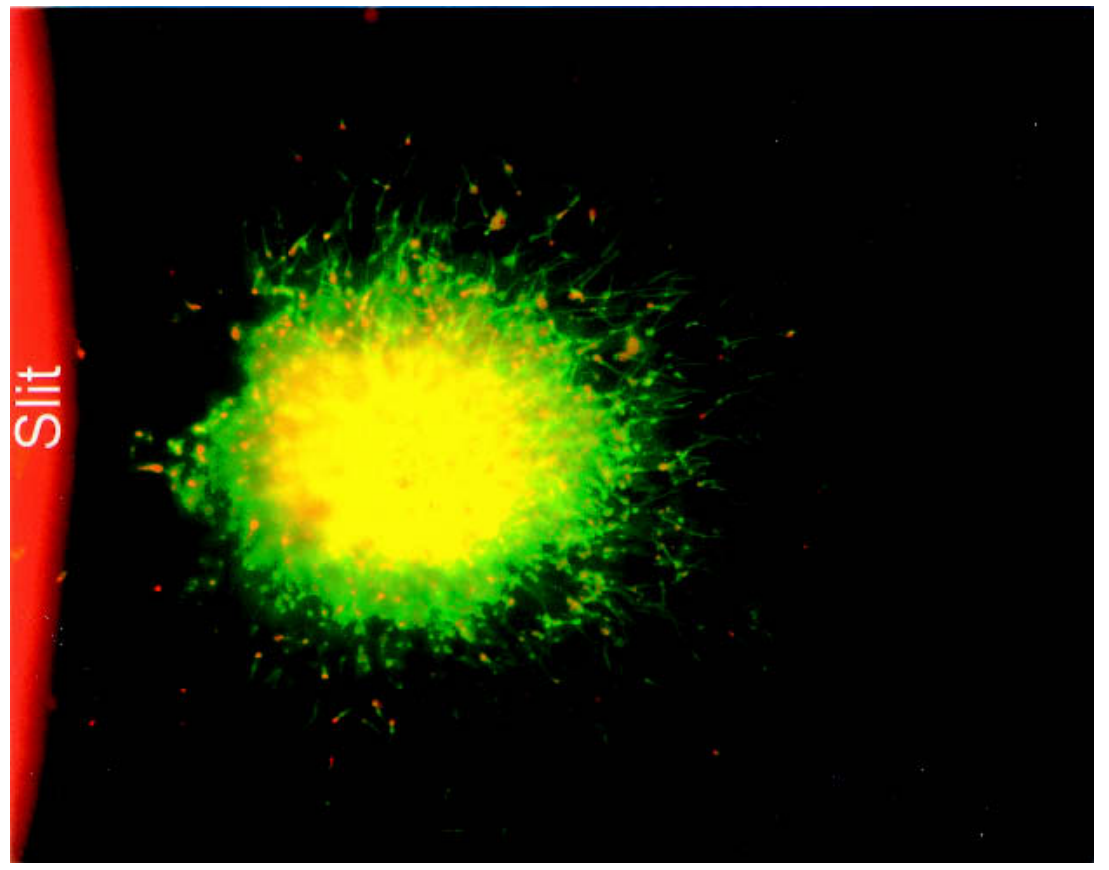


encephlic neuroepithelium to the inferior olivary nucleus (Bloch-Gallego et al. 1999; de Diego et al. 2002).

Netrins may also play a role in establishing or maintaining the rostral boundary of the cerebellum (Przyborski et al. 1998). Netrin-1 is expressed in the pontine area and it has been demonstrated that a loss of function mutation in its receptor, Unc5h3, causes the embryonic EGL cells and Purkinje cell precursors to migrate across the normal rostral boundary into the midbrain (Ackerman et al. 1997; Przyborski et al. 1998). Although netrin-1 repels cerebellar precursor cells postnatally (Alcantara et al. 2000), direct tests of netrin-1 did not show any effect of netrin-1 on EGL cells of the appropriate embryonic stages, suggesting that perhaps other netrins may function through Unc5h3 (Alcantara et al. 2000). In addition to its roles in the cerebellum, netrin repels cells in the MGE and LGE of the telencephalon (Hamasaki et al. 2001).

Precursor cells from the MGE can migrate either into the striatum or the neocortex to become interneurons. Repulsion by Semas is important for directing some interneurons into the neocortex and others into the striatum (Marin et al. 2001). Sema 3A and Sema 3F are expressed in the striatum, whereas its neuropilin receptors are expressed in interneurons migrating from the MGE to the neocortex, but not in interneurons migrating into the striatum (Marin et al. 2001). Sema 3A and its receptor neuropilin-1 may function in repelling or inhibiting the migration of neural crest cells from the trunk and hindbrain (Eickholt et al. 1999; Kawasaki et al. 2002). Sema 3C may promote the migration of neural crest cells into the proximal cardiac outflow tract (Feiner et al. 2001).

Ephrins and their Eph receptors are involved in delineating the migratory pathway of neural crest cells in the peripheral nervous system (PNS) (O'Leary and Wilkinson 1999; Klein 2001; Wilkinson 2001; Knoll and Drescher 2002). Because ephrins are not diffusible, they function by creating regions that are nonpermissive to migrating neural crest cells. In the CNS, ephrins and Eph are expressed in the SVZa and the RMS (Conover et al. 2000). Injection of extracellular domains of Eph receptors can disrupt SVZa migration (Conover et al. 2000), although the precise roles of ephrins in the RMS remain to be defined.

\section{Conservation of guidance cues for neurons and leukocytes}

Since its discovery in the late 1800s, migration has been well known to be a basic feature of cells ranging from leukocytes in adult animals (for review, see McCutcheon 1946; Harris 1954; Devreotes and Zigmond 1988) to neuronal precursor cells in embryos (for review, see Hatten and Mason 1990; Rakic 1990; Hatten and Heintz 1998; Bentivoglio and Mazzarello 1999). Only recently, however, has it become apparent that mechanisms guiding neuronal migration also seem to be shared with those for leukocytes, suggesting a fundamental conservation of directional control of cell migration among distinct cell types. Leukocyte chemotaxis was first described by Leber in 1888 (McCutcheon 1946; Harris 1954) and is one of the best-characterized models of cell migration in adult mammals (Boyden 1962; Zigmond 1974; Devreotes and Zigmond 1988; Servant et al. 2000). Work in the last 20 years has demonstrated the importance of the chemokine family in leukocyte chemotaxis (Baggiolini et al. 1997; Luster 1998; Cyster 1999; Locati and Murphy 1999). The first chemokine was isolated in 1977 (Duel et al. 1977) and functional studies of the chemokines began in 1987 with the identification of interleukin-8 (Yoshimura et al. 1987). There are presently more than 40 chemokines, which are small and structurally related proteins containing 70-100 amino acid residues that promote leukocyte motility and attract leukocytes.

There are multiple differences between neurons and leukocytes, including: (1) different migratory environments; (2) specialized morphologies (a migrating neuron has a single leading process versus leukocytes, which have multiple short pseudopodia; Fig. 3); (3) the speed of neuronal migration is significantly slower than that of leukocyte chemotaxis; and (4) all guidance cues for neurons function through single transmembrane proteins, whereas all leukocyte chemotactic factors function
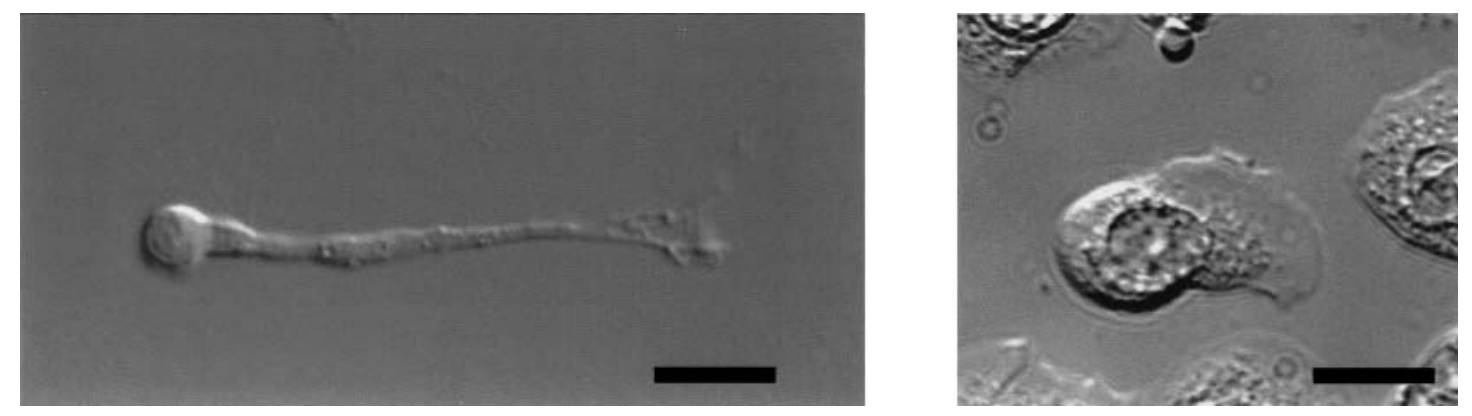

Figure 3. Morphological comparison of a migrating neuron and a chemotactic leukocyte. A neuronal precursor cell from the medial ganglionic eminence is shown on the left and a migrating neutrophil is shown on the right. Pictures were taken under the same microscope with the same magnification. Bars, $10 \mu \mathrm{m}$. Both cells were migrating from the left to the right. In the left panel, the cell body is located in the left and the tip of the leading process is at the right. In the right panel, the neutrophil was differentiated from a PLB cell. The photograph was taken when the cell was migrating after treatment with the chemotactic factor $N$-formyl peptide f-Met-Leu-Phe (fMLP). 
through seven transmembrane proteins coupled to a heterotrimeric $G$ protein. It is thus possible that different mechanisms have evolved to guide the migration of different cell types. However, recent studies indicate that, despite these differences, the guidance cues and receptors for neurons and leukocytes are used in both systems, supporting a conservation of guidance mechanisms for cells of distinct types.

Recently, Slit has been found to control leukocyte chemotaxis (Wu et al. 2001). Two mammalian Slit genes and three Slit receptors (Robos) are expressed in adult tissues outside the nervous system (Wu et al. 2001). Slit could inhibit the migration of monocytes, lymphocytes, and neutrophils induced by multiple types of chemokines and nonchemokine type of chemotactic factors (Wu et al. 2001). The effect of Slit on leukocyte chemotaxis is inhibited by a soluble form of the extracellular domain of Robo (Wu et al. 2001), which was shown earlier to inhibit Slit repulsion of neurons (Wu et al. 1999; Zhu et al. 1999). These results support the idea that the same receptor (and presumably intracellular pathways) is used in both neurons and leukocytes (Wu et al. 1999; Zhu et al. 1999; Wu et al. 2001). In addition to providing evidence for conserved mechanisms of cell migration, these results also suggest a strategy to control unwanted leukocyte chemotaxis. Thus, the inhibitory effect of Slit could be used to attenuate leukocyte infiltration during inflammation (L. Feng, J.Y. Wu, and Y. Rao, unpubl.). Ongoing research indicates that down-regulation of endogenous Slit expression may contribute to inflammation, suggesting that the endogenous Slit and Robo may play roles in leukocyte chemotaxis.

A role for leukocyte guidance cues in neuronal migration has been studied in the case of the chemokine stromal derived factor (SDF)-1. SDF-1 was originally found in the immune system (Tashiro et al. 1993; Nagasawa et al. 1996), where it functions as a chemoattractant for leukocytes through its CXCR4 receptor. When SDF-1 and CXCR4 genes were knocked out, a surprising finding was that cerebellar granule cells were found in the internal layers prematurely in the embryo (Ma et al. 1998; Tachibana et al. 1998; Zou et al. 1998), suggesting that SDF-1 may either directly or indirectly play a role in preventing the EGL cells from premature migration ( $\mathrm{Ma}$ et al. 1998; Zou et al. 1998). However, the precise role of SDF-1 in EGL migration was not known (Ma et al. 1998; Zou et al. 1998; Asensio and Campbell 1999; Mennicken et al. 1999|. Based on the premature neuronal migration phenotype of the SDF-1 knockout mice, one suggestion was that SDF-1 inhibits neuronal differentiation and thus reduces migration (Ma et al. 1998). Another was that SDF-1 increases cell adhesion and thus immobilizes the EGL cells (Zou et al. 1998). Recent work indicates that SDF-1 is expressed in the meninges and can attract cerebellar granule cells (Klein et al. 2001; Lu et al. 2001; Zhu et al. 2002). SDF can attract embryonic but not postnatal EGL cells (Zhu et al. 2002), resulting in the anchoring of embryonic EGL cells. This switch of cellular responsiveness occurs through the inhibition of SDFCXCR4 signaling by Eph and ephrins, which are expressed in the postnatal EGL cells (Lu et al. 2001). Further studies with the hippocampus also indicate a role for SDF-1 and CXCR4 in the migration of dentate granule cells (Bagri et al. 2002a,b; Lu et al. 2002). Thus, the chemokine SDF-1 and its receptor CXCR4 are used both in leukocytes and in neurons. Similar to neuronal response to guidance cues (Song et al. 1998), the attractive responses of leukocytes to SDF-1 can also be reversed by changes in cyclic nucleotide levels (Poznansky et al. 2000), further supporting the idea that guidance mechanisms are conserved between neurons and leukocytes.

Studies of CD100/Sema4D suggest that a ligand similar to those functioning as guidance cues in the nervous system may be used by a different receptor in leukocytes. CD100/Sema4D is a transmembrane Sema similar to human Sema 3A that can be cleaved into a diffusible form (Furuyama et al. 1996; Hall et al. 1996; Hérold et al. 1996; Elhabazi et al. 2001). Although it has not been shown to guide neuronal migration, CD100 is the first member of the Sema family of neuronal guidance cues detected in the immune system. CD100 has multiple functions in lymphocytes including T-cell adhesion (Hérold et al. 1996), B-cell aggregation and survival (Hall et al. 1996), lymphocyte activation (Kumanogoh et al., 2000; Shi et al. 2000; Watanabe et al. 2001), and monocyte migration (Delaire et al. 2001). Neuropilins and plexins are the Sema receptors in the nervous system. It has been demonstrated that the inhibitory effect of CD100 on monocyte migration is not through either neuropilin-1 or neuropilin-2 (Delaire et al. 2001). Instead, CD100 acts on lymphocytes by binding to CD72, a lectin-related transmembrane receptor (Kumanogoh et al. 2000). Furthermore, the effect of CD100 on monocyte migration is not regulated by intracellular cyclic nucleotide levels (Delaire et al. 2001), whereas neuronal responses to Semas are (Song et al. 1998). Therefore, although CD100/Sema4D regulates lymphocyte function and migration, the underlying mechanisms are different from those used to mediate Sema guidance of axons and neurons (Kumanogoh and Kikutani 2001).

\section{Signal transduction mechanisms guiding neuronal migration}

Signaling transduction mechanisms in axon guidance have been reviewed recently (Patel and Van Vactor 2002). We will focus here on the previously mentioned SlitRobo pathway because it is the only pathway that has been directly studied in neuronal migration. It remains to be investigated whether the same pathway is used in both neurons and leukocytes.

Although Slit was discovered over a decade ago, it was only recently that the receptor for Slit was found to be the transmembrane protein Robo (Kidd et al. 1998; Brose et al. 1999; Li et al. 1999). Robo was first discovered for its role in commissural axon guidance in Drosophila (Seeger et al. 1993; Kidd et al. 1998). Studies in Drosophila indicate that slit and robo mutations interact genetically (Kidd et al. 1999). Biochemical studies of 
mammalian Slit and Robo proteins provide direct evidences that Slit binds Robo (Brose et al. 1999; Li et al. 1999), and functional studies indicate that the extracellular part of Robo blocks neuronal responses to Slit (Wu et al. 1999; Zhu et al. 1999).

Robo is a single-pass transmembrane protein with five immunoglobulin (Ig) domains and three fibronectin type III (FNIII) repeats in its extracellular part. Biochemical experiments showed that the Ig domains in Robo are sufficient to interact with the LRR in Slit (Battye et al. 2001; Chen et al. 2001; Nguyen-Ba-Charvet et al. 2001b).

The large intracellular region of Drosophila Robo and the three mammalian Robos contains four identifiable conserved motifs designated $\mathrm{CC} 0, \mathrm{CC} 1, \mathrm{CC} 2$, and $\mathrm{CC} 3$ (Kidd et al. 1998; Zallen et al. 1998). The cytoplasmic domain of Robo is important in mediating repulsion in response to Slit (Bashaw and Goodman 1999). In transgenic flies, neurons expressing a chimeric receptor containing the ectodomain of Frazzled (Fra), a receptor for netrin, and the cytoplasmic domain of Robo (Fra-Robo) avoided the netrin-expressing midline (Bashaw and Goodman 1999), indicating that the cytoplasmic domain of Robo determines the repulsive response. Deletion of each of the CC motifs leads to a partial robo phenotype (Bashaw et al. 2000), suggesting an additive effect of these motifs (Bashaw et al. 2000). The CC2 motif is a consensus binding site for Ena-VASP-homology domain (EVH1) of Enabled (Ena), and in vitro binding experiments suggested that Ena interacted with Robo through CC2 and CC1 (Bashaw et al. 2000). The Abelson kinase (Abl) can phosphorylate Robo in vitro and Abl seems to antagonize the activity of Robo in Drosophila (Bashaw et al. 2000). It is unknown whether Slit can regulate the activities of Abl and Ena. In Drosophila, genetic interaction between ena and slit and that between $a b l$ and robo have been detected (Bashaw et al. 2000), suggesting functional roles of Ena and Abl in the Slit-Robo pathway, at least for commissural axon guidance.

Work in Drosophila has suggested the involvement of protein tyrosine phosphatases (PTPases) in the Slit-Robo pathway (Sun et al. 2000). Mutations in two receptor PTPase genes, PTP10D and PTP69D, interact genetically with slit and robo (Sun et al. 2000). Phenotypic analyses suggest that PTPases increase the sensitivity of commissural axons to Slit (Sun et al. 2000). The roles of Ena, Abl, and PTPases in neuronal migration remain to be determined.

The CC3 motif of Robol interacts with srGAPs, a novel subfamily of GTPase-activating proteins (GAPs; Wong et al. 2001). srGAPs 1 and 2 are expressed in regions responsive to Slit and in patterns similar to that of Robol (Wong et al. 2001). Extracellular interaction between Slit and Robo increases the intracellular interaction between the CC3 motif of Robo and the SH3 motif of the srGAPs. Slit treatment of either a mammalian cell line or the primary SVZa cells reduces the amount of the active form of the Rho GTPase Cdc42 (Wong et al. 2001). The functional role of Cdc42 in neuronal migration has been demonstrated by the observation that the repulsive effect of Slit on migrating SVZa cells was blocked by a constitutively active mutant of Cdc42 (Wong et al. 2001). Whether and how Slit regulates the activities of the other Rho GTPases (RhoA and Rac1) depends on the cell type (Wong et al. 2001), and the functional significance of RhoA and Racl in Slit-Robo signaling is presently unknown.

Because the active form of Cdc42 activates N-WASP, which promotes actin polymerization, a working hypothesis for Slit-mediated repulsion of migrating neurons has been proposed (Wong et al. 2001). This pathway begins with the extracellular interaction of Slit with Robo, and the signal is transduced through the increased intracellular interaction of Robo with srGAPs, resulting in the inactivation of Cdc42. The relatively lower level of Cdc42 activity on the side of the cell proximal to a higher concentration of Slit leads to relatively lower activities of N-WASP and Arp2/3 complex on the proximal side. Eventually, there will be polarized actin polymerization with less actin polymerization on the proximal side and more actin polymerization on the distal side of the cell (Wong et al. 2001). This model remains to be tested biochemically and functionally.

It is unclear whether the Abl, Ena, and the PTPases are intrinsic components of the intracellular pathway for Slit-Robo signaling, or whether some components are only specifically involved in some, but not all, responses. For example, because Drosophila abl and ena mutants do not have all the phenotypes of slit and robo mutants, it is possible that $\mathrm{Abl}$ and Ena are required for commissural axon guidance in Drosophila, but not necessarily for neuronal migration in mammals. It is not known whether Ena and Abl mediate completely different pathways or whether they interact with srGAPs functionally. Similar to other guidance cues, Slit response can be regulated by intracellular concentration of cGMP (NguyenBa-Charvet et al. 2001a). It is unknown whether and how cGMP regulates the hypothetical srGAP-N-WASPArp2/3 pathway.

Genetic studies in Drosophila suggested that Slit promotes the asymmetric division of neural precursor cells by down-regulating specific proteins (Mehta and Bhat 2001). One tempting possibility is that Slit can regulate the polarized activity or localization of some component(s) that are used both in guiding cell migration and in establishing cell polarity.

\section{Concluding remarks}

The importance of neuronal migration is now clearly established, although the full spectrum of functional roles of neuronal migration in evolution, development, and adult life remains to be clarified. Studies of guidance cues that are shared among migrating neurons, projecting axons, and chemotactic leukocytes are advancing our understanding of the spatial control of migration. The potential link between cell adhesion signaling and directional guidance cues remains to be studied at the molecular level. In addition, because the mechanisms involved in polarized neuronal movement are largely unknown and little is known about temporal regulation of 
neuronal migration, additional exploration of these areas will be required. Multiple approaches will thus be required to gain a comprehensive understanding of the mechanisms of neuronal migration and fundamentally conserved mechanisms underlying cell motility and its regulation.

\section{References}

Ackerman, S.L., Kozak, L.P., Przyborski, S.A., Rund, L.A., Boyer, B.B., and Knowles, B.B. 1997. The mouse rostral cerebellar malformation gene encodes an UNC-5-like protein. Nature 386: 838-842.

Adams, N.C., Tomoda, T., Cooper, M., Dietz, G., and Hatten, M.E. 2002. Mice that lack astrotactin have slowed neuronal migration. Development 129: 965-972.

Alcantara, S., Ruiz, M., De Castro, F., Soriano, E., and Sotelo, C. 2000. Netrin 1 acts as an attractive or as a repulsive cue for distinct migrating neurons during the development of the cerebellar system. Development 127: 1359-1372.

Alder, J., Cho, N.K., and Hatten, M.E. 1996. Embryonic precursor cells from the rhombic lip are specified to a cerebellar granule neuron identity. Neuron 17: 389-399.

Altman, J. 1962. Are neurons formed in the brains of adult mammals? Science 135: 1127-1128.

-1969. Autoradiographic and histological studies of postnatal neurogenesis. IV. Cell proliferation and migration in the anterior forebrain, with special reference to persisting neurogenesis in the olfactory bulb. J. Comp. Neurol. 137: 433-458.

Altman, J. and Bayer, S.A. 1997. Development of the cerebellar system. CRC Press, New York.

Altman, J. and Das, G.D. 1966. Autoradiographic and histological studies of postnatal neurogenesis. I. A longitudinal investigation of the kinetics, migration and transformation of cells incorporating tritiated thymidine in neonate rats, with special reference to postnatal neurogenesis in some brain regions. J. Comp. Neurol. 127: 337-390.

Alvarez-Buylla, A. and García-Verdugo, J.M. 2002. Neurogenesis in adult subventricular zone. J. Neurosci. 22: 629-634.

Alvarez-Buylla, A. and Kirn, J.R. 1997. Birth, migration, incorporation, and death of vocal control neurons in adult songbirds. J. Neurobiol. 33: 585-601.

Anderson, S.A., Eisenstat, D.D., Shi, L., and Rubenstein, J.L.R. 1997. Interneuron migration from the basal forebrain to the neocortex: Dependence on Dlx genes. Science 278: 474-476.

Angevine Jr., J.B. and Sidman, R.L. 1961. Autoradiographic study of cell migration during histogenesis of cerebral cortex in the mouse. Nature 192: 766-768.

Anton, E.S., Cameron, R.S. and Rakic, P. 1996. Role of neuronglial junctional domain proteins in the maintenance and termination of neuronal migration across the embryonic cerebral wall. J. Neurosci. 16: 2283-2293.

Anton, E.S., Kreidberg, J.A., and Rakic, P. 1999. Distinct functions of alpha3 and alpha(v) integrin receptors in neuronal migration and laminar organization of the cerebral cortex. Neuron 22: 277-289.

Asensio, V.C. and Campbell, I.L. 1999. Chemokines in the CNS: Plurifunctional mediators in diverse states. Trends Neurosci. 22: 504-512.

Baggiolini, M., Dewald, B., and Moser, B. 1997. Human chemokines: An update. Annu. Rev. Immunol. 15: 675-705.

Bagri, A., Gurney, T., He, X., Zou, Y.-R., Littman, D.R., TessierLavigne, M., and Pleasure, S.J. 2002a. The chemokine SDF1 regulates migration of dentate granule cells. Development 129: 4249-4260.

Bagri, A., Marín, O., Plump, A.S., Mak, J., Pleasure, S.J., Ruebenstein, J.L.R., and Tessier-Lavigne, M. 2002b. Slit proteins prevent midline crossing and determine the dorsoventral position of major axonal pathways in the mammalian forebrain. Neuron 33: 233-248.

Barton, A.R. and Harvey, P.H. 2000. Mosaic evolution of brain structure in mammals. Nature 405: 1055-1058.

Bashaw, G.J. and Goodman, C.S. 1999. Chimeric axon guidance receptors: The cytoplasmic domains of slit and netrin receptors specify attraction versus repulsion. Cell 97: 917-926.

Bashaw, G.J. Kidd, T., Murray, D., Pawson, T., and Goodman, C.S. 2000. Repulsive axon guidance: Abelson and Enabled play opposing roles downstream of the roundabout receptor. Cell 101: 703-715.

Battye, R., Stevens, A., and Jacobs, J.R. 1999. Axon repulsion from the midline of the Drosophila CNS requires slit function. Development 126: 2475-2481.

Battye, R., Stevens, A., Perry, R.L., and Jacobs, J.R. 2001. Repellent signaling by Slit requires the leucine-rich repeats. $I$. Neurosci. 21: 4290-4298.

Bentivoglio, M. and Mazzarello, P. 1999. This history of radial glia. Brain Res. Bull. 49: 305-315.

Bloch-Gallego, E., Ezan, F., Tessier-Lavigne, M., and Sotelo, C. 1999. Floor plate and netrin-1 are involved in the migration and survival of inferior olivary neurons. I. Neurosci. 19: 4407-4420.

Boyden, S. 1962. The chemotactic effect of mixtures of antibody and antigen on polymorphonuclear leukocytes. J. Exp. Med. 115: 453-466.

Brose, K., Bland, K.S., Wang, K.H., Arnott, D., Henzel, W., Goodman, C.S., Tessier-Lavigne, M., and Kidd, T. 1999. Evolutionary conservation of the repulsive axon guidance function of Slit proteins and of their interactions with Robo receptors. Cell 96: 795-806.

Cameron, R.S. and Rakic, P. 1994. Identification of membrane proteins that comprise the plasmalemmal junction between migrating neurons and radial glial cells. J. Neurosci. 14: 3139-3155.

Chazal, G., Durbec, P., Jankovski, A., Rougon, G., and Cremer, H. 2000. Consequences of neural cell adhesion molecule deficiency on cell migration in the rostral migratory stream of the mouse. I. Neurosci. 20: 1446-1457.

Chen, J.H., Wen, L., Dupuis, S., Wu, J.Y., and Rao, Y. 2001. The $\mathrm{N}$-terminal leucine-rich regions in Slit are sufficient to repel olfactory bulb axons and subventricular zone neurons. $J$. Neurosci. 21: 1548-1556.

Chung, C.Y., Funamoto, S., and Firtel, R.A. 2001. Signaling pathways controlling cell polarity and chemotaxis. Trends Biochem. Sci. 26: 557-566.

Colamarino, S.A. and Tessier-Lavigne, M. 1995. The role of the floor plate in axon guidance. Annu. Rev. Neurosci. 18: 497529.

Conover, J.C., Doetsch, F., Garcia-Verdugo, J.M., Gale, N.W., Yancopoulos, G.D., and Alvarez-Buylla, A. 2000. Disruption of Eph/ephrin signaling affects migration and proliferation in the adult subventricular zone. Nat. Neurosci. 3: 1091-1097.

Corbin, J.G., Nery, S., and Fishell, G. 2001. Telencephalic cells take a tangent: Non-radial migration in the mammalian forebrain. Nat. Neurosci. (Suppl.) 4: 1177-1182.

Cyster, J.G. 1999. Chemokines and cell migration in secondary lymphoid organs. Science 286: 2098-2102.

De Carlos, J.A., Lopez-Mascaraque, L., and Valverde, F. 1996. Dynamics of cell migration from the lateral ganglionic eminence in the rat. J. Neurosci. 16: 6146-6156. 
DeDiego, I., Smith-Fernandez, A., Fairen, A. 1994. Cortical cells that migrate beyond area boundaries: Characterization of an early neuronal population in the lower intermediate zone of prenatal rats. Eur. J. Neurosci. 6: 983-997.

de Diego, I., Kyriakopoulou, K., Karagogeos, D., and Wassef, M. 2002. Multiple influences on the migration of precerebellar neurons in the caudal medulla. Development 129: 297-306.

DeFreitas, M.F., Yoshida, C.K., Frazier, W.A., Mendrick, D.L., Kypta, R.M., and Reichardt, L.F. 1995. Identification of integrin alpha 3 beta 1 as a neuronal thrombospondin receptor mediating neurite outgrowth. Neuron 15: 333-343.

Delaire, S., Billard, C., Tordjman, R., Chedotal, A., Elhabazi, A., Bensussan, A., and Boumsell, L. 2001. Biological activity of soluble CD100. II: Soluble CD100, similarly to H-SemaIII, inhibits immune cell migration. J. Immunol. 166: 43484354.

Denaxa, M., Chan, C.H., Schachner, M., Parnavelas, J.G., and Karagogeos, D. 2001. The adhesion molecule TAG-1 mediates the migration of cortical interneurons from the ganglionic eminence along the corticofugal fiber system. Development 128: 4635-4644.

Devreotes, P.N. and Zigmond, S.H. 1988. Chemotaxis in eukaryotic cells: A focus on leukocytes and Dictyostelium. Annu. Rev. Cell Biol. 4: 649-686.

Dhavan, R. and Tsai, L.H.. 2001. A decade of cdk5. Nat. Rev. Mol. Cell Biol. 2: 749-759.

Downey, G.P. 1994. Mechanisms of leukocyte motility and chemotaxis. Curr. Opin. Immunol. 6: 113-124.

Duel, T.F., Keim, P.S., Farmer, M., and Heinrikson, R.L. 1977. Amino acid sequence of human platelet factor 4. Proc. Nat1. Acad. Sci. 74: 2256-2258.

Edmondson, J.C., Liem, R.K., Kuster, J.E., and Hatten, M.E. 1988. Astrotactin: A novel neuronal cell surface antigen that mediates neuron-astroglial interactions in cerebellar microcultures. J. Cell Biol. 106: 505-517.

Eickholt, B.J., Mackenzie, S.L., Graham, A., Walsh, F.S., and Doherty, P. 1999. Evidence for collapsin-1 functioning in the control of neural crest migration in both trunk and hindbrain regions. Development 126: 2181-2189.

Elhabazi, A., Delaire, S., Bensussan, A., Boumsell, L., and Bismuth, G. 2001. Biological activity of soluble CD100. I. The extracellular region of CD100 is released from the surface of $\mathrm{T}$ lymphocytes by regulated proteolysis. I. Immunol. 166: 4341-4347.

Erskine, L., Williams, S.E., Brose, K., Kidd, T., Rachel, R.A., Goodman, C.S., Tessier-Lavigne, M., and Mason, C.A. 2000. Retinal ganglion cell axon guidance in the mouse optic chiasm: Expression and function of robos and slits. J. Neurosci. 20: 4975-4982.

Feiner, L., Webber, A.L., Brown, C.B., Lu, M.M., Jia, L., Feinstein, P., Mombaerts, P., Epstein, J.A., and Raper, J.A. 2001. Targeted disruption of semaphorin $3 \mathrm{C}$ leads to persistent truncus arteriosus and aortic arch interruption. Development 128: 3061-3070.

Fishell, G. and Hatten, M.E. 1991. Astrotactin provides a receptor system for CNS neuronal migration. Development 113: $755-765$.

Fishell, G., Mason, C.A., and Hatten, M.E. 1993. Dispersion of neural progenitors within the germinal zones of the forebrain. Nature 362: 636-638.

Flanagan, J.G. and Vanderhaeghen, P. 1998. The ephrins and Eph receptors in neural development. Annu. Rev. Neurosci. 21: 309-345.

Flint, A.C. and Kriegstein, A.R. 1997. Mechanisms underlying neuronal migration disorders and epilepsy. Curr. Opin. Neurobiol. 10: 92-97.
Furuyama, T., Inagaki, S., Kosugi, A., Noda, S., Saitoh, S., Ogata, M., Iwahashi, Y., Miyazaki, N., Hamaoka, T., and Tohyama, M. 1996. Identification of a novel transmembrane semaphorin expressed on lymphocytes. I. Biol. Chem. 271: 33376-33381.

Gage, F.H. 2000. Mammalian neural stem cells. Science 287: $1433-1438$.

Giese, A. and Westphal, M. 1996. Glioma invasion in the central nervous system. Neurosurgery 39: 235-250.

Goldman, S.A. and Luskin, M.B. 1998. Strategies utilized by migrating neurons of the postnatal vertebrate forebrain. Trends Neurosci. 21: 107-114.

Goldman, S.A. and Nottebohm, F. 1983. Neuronal production, migration and differentiation in a vocal control nucleus of the adult female canary brain. Proc. Natl. Acad. Sci. 80: 2390-2394.

Gould, E. and Gross, C.G. 2002. Neurogenesis in adult mammals: Some progress and problems. J. Neurosci. 22: 619-623.

Graus-Porta, D., Blaess, S., Senften, M., Littlewood-Evans, A., Damsky, C., Huang, Z., Orban, P., Klein, R., Schittny, J.C., and Müller, U. 2001. $\beta 1$-Class integrins regulate the development of laminae and folia in the cerebral and cerebellar cortex. Neuron 31: 367-379.

Gray, G.E., Leber, S.M., and Sanes, J.R. 1990. Migratory patterns of clonally related cells in the developing central nervous system. Experientia 46: 929-940.

Greenough, W.T., West, R.W., and DeVoogd, T.J. 1978. Subsynaptic plate perforations: Changes with age and experience in the rat. Science 202: 1096-1098.

Gregory, W.A., Edmondson, J.C., Hatten, M.E., and Mason, C.A. 1988. Cytology and neuron-glial apposition of migrating cerebellar granule cells in vitro. J. Neurosci. 8: 1728-1934.

Hall, K.T., Boumsell, L., Schultz, J.L., Boussiotis, V.A., Dorfman, D.M., Cardoso, A.A., Bensussan, A., Nadler, L.M., and Freeman, G.J. 1996. Human CD100, a novel leukocyte semaphorin that promotes B cell aggregation and differentiation. Proc. Nat. Acad. Sci. 93: 11780.

Hamasaki, T., Goto, S., Nishikawa, S., and Ushio, Y. 2001. A role of netrin-1 in the formation of the subcortical structure striatum: Repulsive action on the migration of late-born striatal neurons. J. Neurosci. 21: 4272-4280.

Harris, H. 1954. Role of chemotaxis in inflammation. Physiol. Rev. 34: 529-562.

Hatten, M.E. and Heintz, N. 1998. Neurogenesis and migration. In Fundamentals of neuroscience (ed. M. Zigmond). Academic Press, New York.

Hatten, M.E. and Liem, R.H.K. 1981. Astroglia provide a template for the positioning of developing cerebellar neurons in vitro. J. Cell Biol. 90: 622-630.

Hatten, M.E. and Mason, C.A. 1990. Mechanisms of glialguided neuronal migration in vitro and in vivo. Experientia 46: $907-916$.

Heffron, D.S. and Golden, J.A. 2000. DM-GRASP is necessary for nonradial cell migration during chick diencephalic development. J. Neurosci. 20: 2287-2294.

Hérold, C., Elhabazi, A., Bismuth, G., Bensussan, A., and Boumsell, A. 1996. CD100 is associated with CD45 at the surface of human T lymphocytes: Role in T cell homotypic adhesion. J. Immunol. 157: 5262-5268.

Hicks, S.P. and D'Amato, C.J. 1968. Cell migrations to the isocortex in the rat. Anat. Rec. 160: 619-634.

Hinds, J.W. 1968. Autoradiographic study of histogenesis in the mouse olfactory bulb. II Cell proliferation and migration. J. Comp. Neurol. 134: 305-322.

$\mathrm{Hu}, \mathrm{H} .1999$. Chemorepulsion of neuronal migration by Slit2 in the developing mammalian forebrain. Neuron 23: 703-711. 
Hu, H. and Rutishauser, U. 1996. A septum-derived chemorepulsive factor for migrating olfactory interneuron precursors. Neuron 16: 933-940.

$\mathrm{Hu}, \mathrm{H}$., Tomasiewics, H., Magnuson, T., and Rutishauser, U. 1996. The role of polysialic acid in migration of olfactory bulb interneuron precursors in the subventricular zone. Neuron 16: 735-743.

Husmann, K., Faissner, A., and Schachner, M. 1992. Tenascin promotes cerebellar granule cell migration and neurite outgrowth by different domains in the fibronectin type III repeats. J. Cell Biol. 116: 1475-1486.

Kawasaki, T., Bekku, Y., Suto, F., Kitsukawa, T., Taniguchi, M., Nagatsu, I., Nagatsu, T., Itoh, K., Yagi, T., and Fujisawa, H. 2002. Requirement of neuropilin 1-mediated Sema3A signals in patterning of the sympathetic nervous system. Development 129: 671-680.

Kempermann, G. 2002. Why new neurons? Possible functions for adult hippocampal neurogenesis. J. Neurosci. 22: 635638

Kidd, T., Brose, K., Mitchell, K.J., Fetter, R.D., Tessier-Lavigne, M., Goodman, C.S., and Tear, G. 1998. Roundabout controls axon crossing of the CNS midline and defines a novel subfamily of evolutionarily conserved guidance receptors. Cell 92: 205-215.

Kidd, T., Bland, K.S., and Goodman, C.S. 1999. Slit is the midline repellent for the Robo receptor in Drosophila. Cell 96: 785-794.

Klein, R. 2001. Excitatory Eph receptors and adhesive ephrin ligands. Curr. Opin. Cell Biol. 13: 196-203.

Klein, R.S., Rubin, J.B., Gibson, H.D., DeHaan, E.N., AlvarezHernandez, X., Segal, R.A., and Luster, A.D. 2001. SDF-1 $\alpha$ induces chemotaxis and enhances Sonic hedgehog-induced proliferation of cerebellar granule cells. Development 128: 1971-1981.

Knoll, B. and Drescher, U. 2002. Ephrin-As as receptors in topographic projections. Trends Neurosci. 25: 145-149.

Kolodkin, A.L. 1996. Growth cones and the cues that repel them. Trends Neurosci. 19: 507-513.

Komuro, H. and Rakic, P. 1998. Distinct modes of neuronal migration in different domains of developing cerebellar cortex. J. Neurosci. 18: 1478-1490.

Komuro, H., Yacubova, E., Yacubova, E., and Rakic, P. 2001. Mode and tempo of tangential cell migration in the cerebellar external granular layer. J. Neurosci. 21: 527-540.

Koster, R.W. and Fraser, S.E. 2001. Direct imaging of in vivo neuronal migration in the developing cerebellum. Curr. Biol. 11: $1858-1863$.

Kumanogoh, A. and Kikutani, H. 2001. The CD100-CD72 interaction: A novel mechanism of immune regulation. Trends Immunol. 22: 670-676.

Kumanogoh, A., Watanabe, C., Lee, I., Wang, X., Shi, W., Araki, H., Hirata, H., Iwahori, K., Uchida, J., Yasui, T., et al. 2000. Identification of CD72 as a lymphocyte receptor for the class IV semaphorin CD100: A novel mechanism for regulating B cell signaling. Immunity 13: 621-631.

Kyriakopoulou, K., de Diego, I., Wassef, M., and Karagogeos, D. 2002. A combination of chain and neurophilic migration involving the adhesion molecule TAG-1 in the caudal medulla. Development 129: 287-296.

Lauffenburger, D.A. and Horwitz, A.F. 1996. Cell migration: A physically integrated molecular process. Cell 84: 359-369.

Lavdas, A.A., Grigoriou, M., Pachnis, V., and Parnavelas, J.G. 1999. The medial ganglionic eminence gives rise to a population of early neurons in the developing cerebral cortex. J. Neurosci. 19: 7881-7888.
Letinic, K. and Rakic, P. 2001. Telencephalic origin of human thalamic GABAergic neurons. Nat. Neurosci. 4: 931-936.

Letinic, K., Zoncu, R., and Rakic, P. 2002. Origin of GABAergic neurons in the human neocortex. Nature 417: 645-649.

Levitt, P. and Rakic, P. 1980. Immunoperoxidase localization of glial fibrillary acidic protein in radial glial cells and astrocytes of the developing rhesus monkey brain. J. Comp. Neurol. 193: 815-840.

Li, H.S., Chen, J.H., Wu, W., Fagaly, T., Yuan, W.L., Zhou, L., Dupuis, S., Jiang, Z., Nash, W., Gick, C., et al. 1999. Vertebrate Slit, a secreted ligand for the transmembrane protein roundabout, is a repellent for olfactory bulb axons. Cell 96: $807-818$

Locati, M. and Murphy, P.M. 1999. Chemokines and chemokine receptors: Biology and clinical relevance in inflammation and AIDS. Annu. Rev. Med. 50: 425-440.

Lois, C. and Alvarez-Buylla, A. 1994. Long-distance neuronal migration in the adult mammalian brain. Science 264: 11451148.

Lois, C., Garcia-Verdugo, J.-M., and Alvarez-Buylla, A. 1996. Chain migration of neuronal precursors. Science 271: 978-981.

Lu, Q., Sun, E., Klein, R.S., and Flanagan, J.G. 2001. Ephrin-B reverse signaling is mediated by a novel PDZ-RGS protein and selectively inhibits $G$ protein-coupled chemoattraction. Cell 105: 69-79.

Lu, M., Grove, E.A., and Miller, R.J. 2002. Abnormal development of the hippocampal dentate gyrus in mice lacking the CXCR4 chemokine receptor. Proc. Natl. Acad. Sci. 99: 7090-7095.

Luskin, M.B. 1993. Restricted proliferation and migration of postnatally generated neurons derived from the forebrain subventricular zone. Neuron 11: 173-189.

Luster, A.D. 1998. Chemokines-Chemotactic cytokines that mediate inflammation. N. Engl. J. Med. 338: 436-445.

Ma, Q., Jones, D., Borghesani, P.R., Segal, R.A., Nagasawa, T., Kishimoto, T., Bronson, R.T., and Springer, T.A. 1998. Impaired B-lymphopoiesis, myelopoiesis, and derailed cerebellar neuron migration in CXCR4- and SDF-1-deficient mice. Proc. Natl. Acad. Sci. 95: 9448-9453.

Marin, O. and Rubenstein, J.L. 2001. A long, remarkable journey: Tangential migration in the telencephalon. Nat. Rev. Neurosci. 2: 780-790.

Marin, O., Anderson, S.A., and Rubenstein, J.L. 2000. Origin and molecular specification of striatal interneurons. J. Neurosci. 20: 6063-6076.

Marin, O., Yaron, A., Bagri, A., Tessier-Lavigne, M., and Rubenstein, J.L. 2001. Sorting of striatal and cortical interneurons regulated by semaphorin-neuropilin interactions. Science 293: 872-875.

Mason, C.A., Edmondson, J.C., and Hatten, M.E. 1988. The extending astroglial process: Development of glial cell shape, the growing tip, and interactions with neurons. J. Neurosci. 8: 3124-3134.

Mason, H.A., Ito, S., and Corfas, G. 2001. Extracellular signals that regulate the tangential migration of olfactory bulb neuronal precursors: Inducers, inhibitors, and repellents. J. Neurosci. 21: 7654-7663.

McCutcheon, M. 1946. Chemotaxis in leukocytes. Physiol. Rev. 26: 19-336.

Mehta, B. and Bhat, K.M. 2001. Slit signaling promotes the terminal asymmetric division of neural precursor cells in the Drosophila CNS. Development 128: 161-168.

Mennicken, F., Maki, R., de Souza, E.B., and Quirion, R. 1999. Chemokines and chemokine receptors in the CNS: A possible role in neuroinflammation and patterning. Trends Pharmacol. Sci. 20: 3-8. 
Misson, J.P., Austin, C.P., Takahashi, T., Cepko, C.L., and Caviness Jr., V.S. 1991. The alignment of migrating neural cells in relation to the murine neopallial radial glial fiber system. Cereb. Cortex 1: 221-229.

Mitchison, T.J. and Cramer, L.P. 1996. Actin-based cell motility and cell locomotion. Cell 84: 371-379.

Montell, D.J. 1999. The genetics of cell migration in Drosophila melanogaster and Caenorhabditis elegans development. Development 126: 3035-3046.

Nadarajah, B. and Parnavelas, J.G. 2002. Modes of neuronal migration in the developing cerebral cortex. Nat. Rev. Neurosci. 3: 423-432.

Nadarajah, B., Brunstrom, J.E., Grutzendler, J., Wong, R.O., and Pearlman, A.L. 2001. Two modes of radial migration in early development of the cerebral cortex. Nat. Neurosci. 4: 143150.

Nadarajah, B., Alifragis, P., Wong, R.O., and Parnavelas, J.G. 2002. Ventricle-directed migration in the developing cerebral cortex. Nat. Neurosci. 5: 218-224.

Nagasawa, T., Hirota, S., Tachibana, K., Takakura, N., Nishikawa, S., Kitamura, Y., Yoshida, N., Kikutani, H., and Kishimoto, T. 1996. Defects of B-cell lymphopoiesis and bonemarrow myelopoiesis in mice lacking the CXC chemokine PBSF/SDF-1. Nature 382: 635-638.

Nguyen-Ba-Charvet, K.T., Brose, K., Marillat, V., Sotelo, C., Tessier-Lavigne, M., and Chedotal, A. 2001a. Sensory axon response to substrate-bound Slit2 is modulated by laminin and cyclic GMP. Mol. Cell. Neurosci. 17: 10481058.

NguyenBa-Charvet, K.T., Brose, K., Ma, L., Wang, K.H., Marillat, V., Sotelo, C., Tessier-Lavigne, M., and Chedotal, A. 2001b. Diversity and specificity of actions of Slit2 proteolytic fragments in axon guidance. J. Neurosci. 21: 42814289.

Niclou, S.P., Jia, L., and Raper, J.A. 2000. Slit2 is a repellent for retinal ganglion cell axons. J. Neurosci. 20: 4962-4974.

Norman, M.G., McGillivray, B.C., Kalousek, D.K., Hill, A., and Poskitt, K.J. 1995. Neuronal migration disorders and cortical dysplasias. Part I. Migration disorders. In: Congenital malformations of the brain: Pathologic, embryological, clinical, radiological and genetic aspects (ed. M.G. Norman), pp. 223-277. Oxford University Press, New York.

Nottebohm, F. 1981. A brain for all seasons: Cyclical anatomical changes in song control nuclei of the canary brain. Science 214: 1368-1370.

. 2002. Why are some neurons replaced in adult brain? $J$. Neurosci. 22: 24-28.

Nowakowski, R.S. and Rakic, P. 1979. The mode of migration of neurons to the hippocampus: A Golgi and electron microscopic analysis in foetal rhesus monkey. I. Neurocytol. 8: $697-718$.

Nusslein-Volhard, C., Wieschaus, E., and Kluding, H. 1984. Mutations affecting the pattern of the larval cuticle in Drosophila melanogaster. I. Zygotic loci on the second chromosome. Rouxs Arch. Dev. Biol. 193: 267-282.

Ogren, M.P. and Rakic, P. 1981. The prenatal development of the pulvinar in the monkey: ${ }^{3} \mathrm{H}$-thymidine autoradiographic and morphometric analyses. Anat. Embryol. 162: 120.

O'Leary, D.D. and Wilkinson, D.G. 1999. Eph receptors and ephrins in neural development. Curr. Opin. Neurobiol. 9: $65-73$.

Ono, K., Tomasiewicz, H., Magnuson, T., and Rutishauser, U. 1994. N-CAM mutation inhibits tangential neuronal migration and is phenocopied by enzymatic removal of polysialic acid. Neuron 13: 595-609.
O'Shea, K.S., Rheinheimer, J.S., and Dixit, V.M. 1990. Deposition and role of thrombospondin in the histogenesis of the cerebellar cortex. J. Cell Biol. 110: 1275-1283.

Parent, C.A. and Devreotes, P.N. 1999. A cell's sense of direction. Science 284: 765-770.

Parnavelas, J.G. 2000. The origin and migration of cortical neurones: New vistas. Trends Neurosci. 23: 126-131.

Patel, B.N. and Van Vactor, D.L. 2002. Axon guidance: The cytoplasmic tail. Curr. Opin. Cell Biol. 14: 221-229.

Poznansky, M.C., Olszak, I.T., Foxall, R., Evans, R.H., Luster, A.D., and Scadden, D.T. 2000. Active movement of T cells away from a chemokine. Nat. Med. 6: 543-548.

Przyborski, S.A., Knowles, B.B., Ackerman, S.L. 1998. Embryonic phenotype of Unc5h3 mutant mice suggests chemorepulsion during the formation of the rostral cerebellar boundary. Development 125: 41-50.

Rakic, P. 1971a. Neuron-glia relationship during granule cell migration in developing cerebellar cortex. J. Comp. Neurol. 141: 283-312.

. 1971b. Guidance of neurons migrating to the fetal monkey neocortex. Brain Res. 33: 471-476.

. 1972. Mode of cell migration to the superficial layers of fetal monkey neocortex. J. Comp. Neurol. 145: 61-84.

1978. Neuronal migration and contact guidance in the primate telencephalon. Postgrad. Med. I. (Suppl.) 54: 2537.

. 1990. Principles of neural cell migration. Experientia 46: $882-891$

2002. Adult neurogenesis in mammals: An identity crisis. J. Neurosci. 22: 614-618.

Rakic, P. and Sidman, R.L. 1969. Telencephalic origin of pulvinar neurons in the fetal human brain. Z. Anat. Entwicklungsgesch. 129: 53-82.

Rao, Y. and Wu, J.Y. 2001. Neuronal migration and the evolution of the human brain. Nat. Neurosci. 4: 860-862.

Raper, J.A. 2000. Semaphorins and their receptors in vertebrates and invertebrates. Curr. Opin. Neurobiol. 10: 88-94.

Reiner, O., Carrozzo, R., Shen, Y., Wehnert, M., Faustinella, F., Dobyns, W.B., Caskey, C.T., and Ledbetter, D.H. 1993. Isolation of a Miller-Dieker lissencephaly gene containing G protein beta-subunit-like repeats. Nature 364: 717-721.

Reynolds, B.A. and Weiss, S. 1992. Generation of neurons and astrocytes from isolated cells of the adult mammalian central nervous system. Science 255: 1707-1710.

Rice, D.S. and Curran, T. 2001. Role of the Reelin signaling pathway in central nervous system development. Annu. Rev. Neurosci. 24: 1005-1039.

Ross, M.E. and Walsh, C.A. 2001. Human brain malformations and their lessons for neuronal migration. Annu. Rev. Neurosci. 24: 1041-1070.

Rothberg, J.M. and Artavanis-Tsakonas, S. 1992. Modularity of the slit protein. Characterization of a conserved carboxyterminal sequence in secreted proteins and a motif implicated in extracellular protein interactions. J. Mol. Biol. 227: $367-370$

Rothberg, J.M., Hartley, D.A. Walther, Z., and Artavanis-Tsakonas, S. 1988. Slit: An EGF-homologous locus of D. melanogaster involved in the development of the embryonic central nervous system. Cell 55: 1047-1059.

Rothberg, J.M., Jacob, J.R., Goodman, C.S., and Artavanis-Tsakonas, S. 1990. Slit: An extracellular protein necessary for the development of midline glia and commissural axon pathways contains both EGF and LRR domains. Genes \& Dev. 4: 2169-2187.

Seeger, M., Tear, G., Ferres-Marco, D., and Goodman, C.S. 1993. Mutations affecting growth cone guidance in Drosophila: 
Genes necessary for guidance toward or away from the midline. Neuron 10: 9-26.

Servant, G., Weiner, O.D., Herzmark, P., Balla, T., Sedat, J.W., and Bourne, H.R. 2000. Polarization of chemoattractant receptor signaling during neutrophil chemotaxis. Science 287: 1037-1040.

Shi, W., Kumanagoh, A., Watanabe, C., Ushida, J., Wang, X., Yasui, T., Yukawa, K., Ikawa, M., Okabe, M., Parnes, J.R., et al. 2000. The class IV semaphorin CD100 plays nonredundant roles in the immune system: Defective $\mathrm{B}$ and $\mathrm{T}$ cell activation in CD100-deficient mice. Immunity 13: 633642 .

Song, H.-J., Ming, G.-L., He, Z., Lehmann, M., McKerracher, L., Tessier-Lavigne, M., and Poo, M.-M. 1998. Conversion of neuronal growth cone responses from repulsion to attraction by cyclic nucleotides. Science 281: 1515-1518.

Stitt, T.N. and Hatten, M.E. 1990. Antibodies that recognize astrotactin block granule neuron binding to astroglia. Neuron 5: 639-649.

Sun, Q., Bahri, S., Schmid, A., Chia, W., and Zinn, K. 2000. Receptor tyrosine phosphatases regulate axon guidance across the midline of the Drosophila embryo. Development 127: 801-812.

Tachibana, K., Hirota, S., Iizasa, H., Yoshida, H., Kawabata, K., Kataoka, Y., Kitamura, Y., Matsushima, K., Yoshida, N., Nishikawa, S., et al. 1998. The chemokine receptor CXCR4 is essential for vascularization of the gastrointestinal tract. Nature 393: 591-594.

Tamamaki, N., Fujimori, K.E., and Takauji, R. 1997. Origin and route of tangentially migrating neurons in the developing neocortical intermediate zone. J. Neurosci. 17: 8313-8323.

Tashiro, K., Tada, H., Heilker, R., Tashiro, K., Tada, H., Heilker, R., Shirozu, M., Nakano, T., and Honjo, T. 1993. Signal sequence trap: A cloning strategy for secreted proteins and type I membrane proteins. Science 261: 600-603.

Tilney, F. 1933. Behavior in its relation to the development of the brain. Part II. Correlation between the development of the brain and behavior in the albino rat from embryonic states to maturity. Bulletin of the Neurological Institute of New York 3: 252-358.

Tomsiewicz, H., Ono, K., Yee, D., Thompson, C., Coridis, C., Rutishauser, U., and Magnuson, T. 1993. Genetic deletion of a neural cell adhesion molecule variant (N-CAM 180) produces distinct defects in the central nervous system. Neuron 11: $1163-1174$.

Van Eden, C.G., Mrzljak, L., Voorn, P., and Uylings, H.B.M. 1989. Prenatal development of GABA-ergic neurons in the neocortex of the rat. J. Comp. Neurol. 289: 213-227.

Volpe, J. 1987. Neurology of the newborn, 2nd ed. Saunders, Philadelphia.

Walsh, C. and Cepko, C. 1990. Cell lineage and cell migration in the developing cerebral cortex. Experientia 46: 940-947.

Watanabe, C., Kumanogoh, A., Shi, W., Suzuki, K., Yamada, S. Okabe, M., Yoshida, K., and Kikutani, H. 2001. Enhanced immune responses in transgenic mice expressing a truncated form of the lymphocyte semaphorin CD100. J. Immunol. 167: 4321-4328.

Wichterle, H., Garcia-Verdugo, J.M., and Alvarez-Buylla, A. 1997. Direct evidence for homotypic, glia-independent neuronal migration. Neuron 18: 779-791.

Wichterle, H., Turnbull, D.H., Nery, S., Fishell, G., and AlvarezBuylla, A. 2001. In utero fate mapping reveals distinct migratory pathways and fates of neurons born in the mammalian basal forebrain. Development 128: 3759-3771.

Wilkinson, D.G. 2001. Multiple roles of EPH receptors and ephrins in neural development. Nat. Rev. Neurosci. 2: 155-164.
Wingate, R.J. 2001. The rhombic lip and early cerebellar development. Curr. Opin. Neurobiol. 11: 82-88.

Wingate, R.J.T. and Hatten, M.E. 1999. The role of the rhombic lip in avian cerebellum development. Development 126: 4395-4404.

Wong, K., Ren, X.R., Huang, Y.Z., Xie, Y., Liu, G., Saito, H., Tang, H., Wen, L., Brady-Kalnay, S.M., Mei, L., et al. 2001. Signal transduction in neuronal migration: Roles of GTPase activating proteins and the small GTPase Cdc42 in the SlitRobo pathway. Cell 107: 209-221.

Wong, K., Park, H.T., Wu, J.Y., and Rao, Y. 2002. Slit proteins: Guidance cues for cells ranging from neurons to leukocytes. Curr. Opin. Genet. Dev. 12: 583-591.

Wu, W., Wong, K., Chen, J.H., Jiang, Z.H., Dupuis, S., Wu, J.Y., and Rao, Y. 1999. Directional guidance of neuronal migration in the olfactory system by the secreted protein Slit. Nature 400: 331-336.

Wu, J.Y., Feng, L., Park, H.-T., Havlioglu, N., Wen, L., Tang, H., Bacon, K.B, Jiang, Z., Zhang, X.-C., and Rao, Y. 2001. The neuronal repellent Slit inhibits leukocyte chemotaxis induced by chemotactic factors. Nature 410: 948-952.

Yan, X.X., Zheng, D.S., and Garey, L.J. 1992. Prenatal development of GABA-immunoreactive neurons in the human striate cortex. Brain Res. Dev. Brain Res. 65: 191-204.

Yee, K.T., Simon, H.H., Tessier-Lavigne, M., and O'Leary, D.D.M. 1999. Extension of long leading processes and neuronal migration in the mammalian brain directed by the chemoattractant netrin-1. Neuron 24: 607-622.

Yoshimura, T., Matsushima, K., Tanaka, S., Robinson, E.A., Appella, E., Oppenheim, J.J., and Leonard, E.J. 1987. Purification of a human monocyte-derived neutrophil chemotactic factor that has peptide sequence similarity to other host defense cytokines. Proc. Nat1. Acad. Sci. 84: 9233-9237.

Zallen, J.A., Yi, B.A., and Bargmann, C.I. 1998. The conserved immunoglobulin superfamily member SAX-3/Robo directs multiple aspects of axon guidance in C. elegans. Cell 92: 217-227.

Zheng, C., Heintz, N., and Hatten, M.E. 1996. CNS gene encoding astrotactin, which supports neuronal migration along glial fibers. Science 272: 417-419.

Zhu, Y., Li, H.S., Zhou, L., Wu, J.Y., and Rao, Y. 1999. Cellular and molecular guidance of GABAergic neuronal migration from the striatum to the neocortex. Neuron 23: 473-485.

Zhu, Y., Yu, T., Zhang, X.-C., Nagasawa, T., Wu, J.Y., and Rao, Y. 2002. Role of the chemokine SDF-1 as the meningeal attractant for embryonic cerebellar neurons. Nat. Neurosci. 5: 719-720.

Zigmond, S.H. 1974. Mechanisms of sensing chemical gradients by polymorphonuclear leukocytes. Nature 249: 450-452.

Zou, Y.R., Kottmann, A.H., Kuroda, M., Taniuchi, I., and Littman, D.R. 1998. Function of the chemokine receptor CXCR4 in haematopoiesis and in cerebellar development. Nature 393: 595-599. 


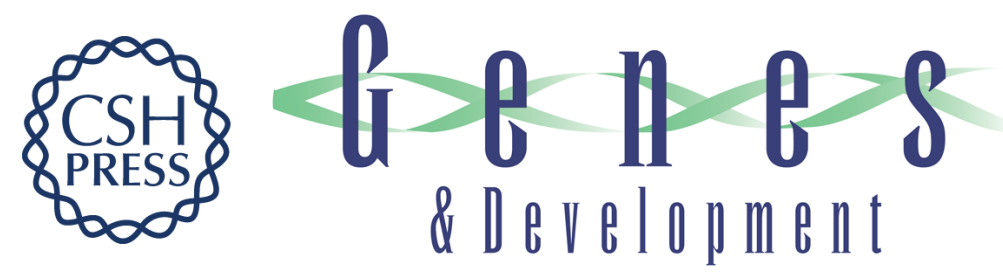

\section{Neuronal migration and molecular conservation with leukocyte chemotaxis}

Yi Rao, Kit Wong, Michael Ward, et al.

Genes Dev. 2002, 16:

Access the most recent version at doi:10.1101/gad.1005802

References This article cites 183 articles, 67 of which can be accessed free at:

http://genesdev.cshlp.org/content/16/23/2973.full.html\#ref-list-1

License

Email Alerting Receive free email alerts when new articles cite this article - sign up in the box at the top Service right corner of the article or click here.

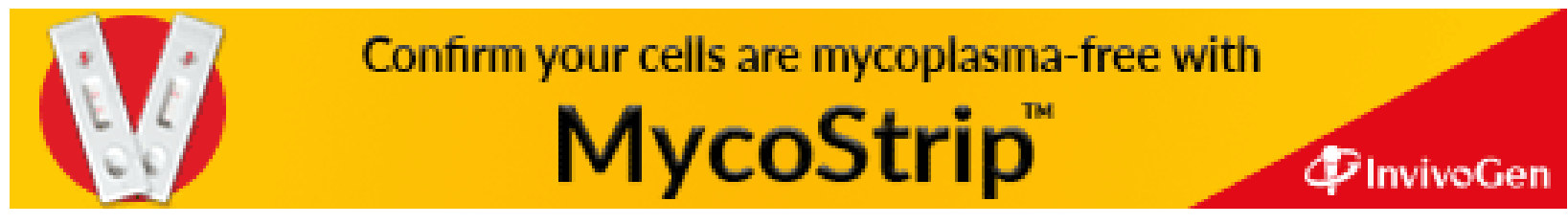

